\title{
The professional autonomy of nursing in pandemic times
}

\section{Rafaela Lira Mendes Costa ${ }^{a}$ \\ Regina Maria dos Santos \\ Laís de Miranda Crispim Costa ${ }^{a}$}

\section{How to cite this article:} Costa RLM, Santos RM, Costa LMC The professional autonomy of nursing in pandemic times. Rev Gaúcha Enferm. 2021;42(spe):e20200404. doi: https://doi.org/10.1590/19831447.2021.20200404
Universidade Federal de Alagoas (UFAL), Escola de Enfermagem, Programa de Pós-Graduação em Enfermagem. Maceió, Alagoas, Brasil.

\section{ABSTRACT}

Objective: To reflect on the exercise of Nursing's professional autonomy in times of pandemic.

Method: Theoretical reflection in the light of the Sociology of Professions proposed by Eliot Freidson. Using the author's main concepts, it was sought to understand the professional practice of Nursing in times when its protagonism in the care process becomes even more challenging.

Results: Although there are obstacles in the daily work, it is believed that an autonomous practice contributes satisfactorily to the performance of nurses, since by revealing all the potential and leadership they have, they allow their professional autonomy to be legitimized.

Final Considerations: The reflection clarified the importance of nurses to put their professional autonomy into practice, in order to achieve greater recognition and social appreciation of their work in times of pandemic.

Keywords: Professional autonomy. Nurses. Nursing care. Professional practice. Pandemics. Coronavirus infections,

\section{RESUMO}

Objetivo: Refletir sobre o exercício da autonomia profissional da Enfermagem em tempos de pandemia.

Método: Reflexão teórica à luz da Sociologia das Profissões proposta por Eliot Freidson. Utilizando-se os principais conceitos do autor, buscou-se uma compreensão sobre o exercício profissional da Enfermagem em tempos onde seu protagonismo frente ao processo de cuidar torna-se ainda mais desafiador.

Resultados: Apesar de existirem obstáculos no cotidiano de trabalho, acredita-se que uma prática autônoma contribui de forma satisfatória para o desempenho de enfermeiras(os), pois, a revelarem todo o potencial e liderança que possuem, permitem que sua autonomia profissional seja legitimada.

Considerações Finais: A reflexão esclareceu a importância de enfermeiras(os) colocarem em prática sua autonomia profissional, com o intuito de alcançarem um maior reconhecimento e valorização social do seu trabalho em tempos de pandemia.

Palavras-chave: Autonomia profissional. Enfermeiras e enfermeiros. Cuidados de enfermagem. Prática profissional. Pandemias. Infecções por coronavírus.

RESUMEN

Objetivo: Reflexionar sobre el ejercicio de la autonomía profesional de la Enfermería en tiempos de pandemia.

Método: Reflexión teórica a la luz de la Sociología de las Profesiones propuesta por Eliot Freidson. Utilizando los conceptos principales de la autora, buscamos comprender la práctica profesional de la Enfermería en momentos en que su protagonismo en el proceso asistencial se vuelve aún más desafiante.

Resultados: Si bien existen obstáculos en el trabajo diario, se cree que una práctica autónoma contribuye satisfactoriamente al desempeño de las enfermeiras y los enfermeros, ya que al revelar todo el potencial y liderazgo que tienen, permiten legitimar su autonomía profesional.

Consideraciones Finales: La reflexión aclaró la importancia de que el enfermero ponga en práctica su autonomía profesional, con el fin de lograr un mayor reconocimiento y valoración social de su trabajo en tiempos de pandemia.

Palabras clave: Autonomía profesional. Enfermeras y enfermeros. Atención de enfermería. Práctica profesional. Pandemias. Infecciones por coronavirus. 


\section{口INTRODUCTION}

The COVID-19 (Coronavirus Disease) is one of the greatest worldwide sanitary challenges of the 21 st century. With this public health crisis installed, the crisis in the Single Health System (SUS) becomes more visible, since the system faces countless structural and organizational challenges, among which: its operational capacity for attention, the number of professionals, and their qualifications ${ }^{(1)}$.

In the frontline of the struggle against COVID-19, nurses stand out as the largest workforce, representing approximately $59 \%$ of the health professionals ${ }^{(2)}$. This highlights the need to reinvent and value the profession. The strengthening of nursing leadership has been attempted, but even with their important role in confronting the pandemic, their political relevance is lacking, as is their small role in management, so they can make decisions and conquer rights ${ }^{(3)}$.

Since the pandemic of the new coronavirus began, the media has been showing testimonies of the courage and sacrifice of nurses who fight without rest to guarantee ethical, respectful, and humane care, even when in less-than-ideal conditions. Working as a nurse in pandemic times is a great challenge for all professionals in this category.

Considering this setting, the nursing field seeks to establish itself as a science and to reinvent its fight for professional valorization and for technical, scientific, financial, and social recognition ${ }^{(1)}$. With the understanding that the role of nursing is singular and essential for patient care, it is important to guarantee the exercise of its professional autonomy in all spaces where they act, to give them a stronger power of decision as they carry out their work.

Professional autonomy represents the freedom a profession has, with regard to other groups, to control a certain field of knowledge and carry out work as they find convenient, without depending on other professions for their routine practices. This is the type of autonomy from which professional power is extracted, and it must be articulated with other aspects that guarantee its preservation and efficiency ${ }^{(4)}$, which will be addressed throughout this discussion.

Nursing professional autonomy takes place when the nurse, with moral and intellectual independence, takes advantage of the ability to guide themselves by their own means, making free decisions and establishing their collective or individual practice, thus managing to make conscious decisions among the options available. Furthermore, when this professional has a high level of autonomy, they can bestow value and social recognition upon their actions ${ }^{(5)}$, in addition to the empowerment provided by their domain over knowledge, generating satisfactory results in their work ${ }^{(6)}$.
However, their professional autonomy is still limited within health organizations ${ }^{(5)}$. Studies about the autonomy of nurses in the hospital environment have shown that these professionals face difficulties in the autonomous performance of their functions, due to conflicting relations with their medical team, high workloads, hospital norms, and existing administrative deficiencies ${ }^{(7-8)}$.

In this regard, the professional autonomy of nurses is seen as a complex question, due to influences from the social structure in which the work is carried out and to the obstacles daily life imposes for this to be achieved. Resisting these influences and overthrowing the barriers that prevent consolidating professional autonomy enables a better performance and strengthen the relationship between health team members and patients and their relatives ${ }^{(9)}$.

Considering the ideas above as a starting point, this study is guided by the following question: what reflection is necessary about the professional autonomy of nurses who are acting in the frontlines of the struggle against the new coronavirus? The relevance of this reflection is justified by the fights for professional space, recognition, and valorization, which have always been present in the trajectory of nursing, and which, currently, have been more intense due to the new coronavirus pandemic, challenging nurses to put in practice their professional autonomy so they can deal better with their decisions and choices during the exercise of their profession in many different work environments. Therefore, the objective of this work is reflecting on the exercise of professional autonomy in nursing in pandemic times.

\section{$\square$ METHOD}

This is a theoretical-reflexive study under the light of the sociology of professions proposed by Eliot Freidson, a prominent North American sociologist, using the concepts of professional autonomy, status, expertise, and self-regulation. This sociological approach was chosen due to the good reception Freidson's work has had among Brazilian researchers in the last decade. This sociologist has become a great luminary in the researches about professional autonomy ${ }^{(6,10-11)}$, and his discussions with regard to the profession apply to field of health.

Freidson alleges that, for something to be considered a profession, there must be a specific formation, training, and the creation of specific knowledge, an idea included in all his writings, since the 70th decade of the 20th century. This stands out in the sociology of professions, since Freidson values the perspective of cognition, which explains professional organization and how professions reach autonomy as they produce specific knowledge ${ }^{(10)}$. 
Although the writings of Freidson seem to indicate that he sees nursing as a para-profession, that is, one that depends on the determinations of another professional for its practice( ${ }^{(4)}$, it is relevant to have a critical dialog with his ideas, since they are a pillar for the construction of this reflection, allowing authors to defend nursing as an autonomous profession, with its own knowledge, on which the practice of caring for people in the reality of their lives is based.

To broaden the debate and contribute with a good reflection about the professional autonomy of nursing in pandemic times, this study was based on national and international scientific literatures, including books, electronic documents, and news published in reference sites.

\section{$\square$ RESULTS AND DISCUSSION}

From the perspective of the Sociology of Professions, all professional groups seek autonomy. The greater the status of a profession, the more its autonomy is validated, since it is organized and recognized, deliberately, when one achieves the right of controlling one's own job. That includes determining who, legally, can carry it out, and how it should be performed ${ }^{(4)}$. Autonomy depends on certain conditions, such as the ability of making independent decisions, being free from coercion, having relational and reflexive thoughts, in addition to knowledge and adequate information ${ }^{(11)}$.

In the case of nursing, the work is an integral part of health care, and involves a division of work organized within a hierarchy, the same logic Freidson describes ${ }^{(4)}$. Since nurses assume the role of leaders, they take control over the actions of nursing technicians and/or auxiliaries, meaning they show autonomy as they occupy a privileged position in their specific field of action.

This professional autonomy, also called heteronomy, is recognized as a right of Brazilian nurses in a specific legislation, Law n. 7.498 , from June 23, 1986. Freidson advocates that a profession, when protected by its autonomy, develops itself based on its own knowledge, and manages to convince people that its practitioners are particularly reliable ${ }^{(4)}$.

Knowledge, when acquired through academic formation, is the base of professional autonomy and of the criteria for action ${ }^{(11)}$. This is the case of nurses, who need a specific higher education formation and a peculiar theoretical body of study. Furthermore, the ethical exercise of the profession is based on an ethics code required specifically for this profession, which is enforced and inspected by a representative organ of the profession itself ${ }^{(10)}$.

However, nurses are still struggling to exercise their professional autonomy in the work in health, not only by making this exercise concrete, but also to reach a certain status and to see their work valued in society. According to Freidson's sociological approach, professional status is the assuming of a position of technical and legal authority in the division of labor, which gives power to a profession (4).

This status becomes broader and is established from the relation between the true knowledge built in the heart of the professions and the way said knowledge is used. Furthermore, the importance of a profession such as nursing in society is a specific attribute that makes solving health and disease situations essential ${ }^{(10)}$.

In a time of tragedies and public health crises, the identity of nursing becomes stronger, encouraging its professionalization and reinforcing its legacy for health care and for the protection of life. In the COVID-19 setting, nursing professionals expect to be respected financially, ethically, and professionally, while governors, managers, and society as a whole understand the importance of nursing. As the action of nurses during the pandemic is analyzed, it can be noticed that the work performed by these professionals has become more visible, as demonstrated by news and reports that show their heroic feats and the difficult work they face.

A proof of that is the case of the nurse Zhang Wendan, who worked in a hospital in the district of Wuhan, the initial epicenter of the COVID-19 pandemic in China, which affected the entire world. The experience reported by this professional was distressing, since she needed to adopt extreme measures in her workplace to avoid interrupting services and preventing cross-infection. Considering the scarcity of personal protective equipment (PPE), she had to get used to wear ill-fitting clothes that were covered in sweat, and needed to cut her hair entirely when she remained thirty days in the quarantine zone of the hospital, having to wear geriatric diapers donated by volunteers due to how difficult it was for her to deal with her menstruation period during work ${ }^{(12)}$.

Considering this situation, it could be noted that, in spite of her exhausting and difficult work routine during the pandemic, she managed to work resiliently in the frontlines. Stories like this one, of courage and dedication to patients, are frequently told by nurses, and only reiterate how important and irreplaceable nurses have always been for the health systems throughout the world.

It should be highlighted that, when a profession organizes itself to guarantee good work, targeted at the public interest, it can be concluded that it justified its demands with regard to its working conditions ${ }^{(4)}$. Considering the precarious nature of work during the pandemic, whether in hospitals or primary health care units, nurses have become more vulnerable and less autonomous, since they are submitted to inadequate working conditions, low wages, long and intense work hours, 
in addition to assuming multiple and distinct activities and having more than one job to increase their income ${ }^{(6)}$.

In addition to the difficulties caused by the pandemic, the work of nurses is also affected by a health model focused on the image of the physician, and society does not value nursing professionals as it does medical ones. This can lead to dissatisfaction or even diminish the motivation of nurses, directly interfering in the autonomous exercise of their work ${ }^{(13)}$.

From the point of view of the Sociology of Professions, the position of nursing is different from that occupied by medicine. Nurses are encouraged to claim for professional status through the development of a curriculum which respects the standards of their formation, through the creation or discovery of an abstract theory, through the formulation of ethical standards or the search of support to exercise a certain control over who is authorized to work in the profession ${ }^{(4)}$, and all these attributes have been achieved.

However, what nurses have not been able to achieve is complete autonomy in the concrete exercise of their work, when compared to medicine ${ }^{(4-6)}$. It is important to highlight that, since the time of Florence Nightingale, the entire nursing service was already submitted to the orders of physicians. Only in the turn from the 19th to the 20th century nurses reached the conclusion that nursing was neither a diminished medicine nor an added profession to deal with the functions physicians did not want to perform, which led them to find a new and independent position in the division of labor ${ }^{(4)}$.

It is important to mention, in this discussion, an important issue that is taking place in the State of Virginia, in the United States, where nurses are prevented from work with professional autonomy. Local regulations, which already existed before the pandemic, state that nurses can only act under medical supervision regardless of the situation, and that, to exercise the profession autonomously or even voluntarily, they had to work for five years under the supervision of a physician. This lack of autonomy has interfered directly in the work of nurses, since many of them have been losing their jobs when physicians decide to close their clinics. This problem drives nurses to go to neighboring states, where they can act autonomously during the pandemi $\mathrm{c}^{(14)}$.

This situation can be seen as a clear example of the loss of professional autonomy, since these American nurses did not demand, from the State, the adequate authorization to carry out their activities as they saw fit. The search for work in other locations is likely to be a way these nurses found to overcome this medical subordination in the performance of their activities.
It is also worth mentioning a research from the $\mathrm{WHO}$, carried out in more than 190 countries, from July to November 2019. Its data showed that the role of nurses is more advanced in countries where there is a small number of physicians, suggesting that increasing the autonomy of nurses could be a political response to mitigate the scarcity of physicians in these countries ${ }^{(2)}$.

According to Freidson, most nurses cannot achieve autonomy due to the fact they work in a hospital, since many of them depend on orders and demands from physicians, which makes conflict more likely ${ }^{(4)}$. This environment is permeated by the forms assumed by the exercise of power, which normalizes the behavior of these professionals and makes their reinvention as autonomous subjects more difficult. However, spaces of resistance are made more viable, capable of weakening the traditional hegemony in health institutions, making it possible for nurses to reinvent their governability ${ }^{(5)}$.

Therefore, nurses must make a choice: either they learn to find satisfaction as physician subordinates, or they find an independent way to legitimate their work ${ }^{(4)}$, which allows them to exercise their activities with the professional autonomy they deserve. It should be highlighted that this autonomy can only become concrete through the construction of their own field of knowledge, one that is not subsidiary to medical practices ${ }^{(5-6)}$.

That is why nurses are still struggling to conquer their autonomy, seeking to affirm nursing as a science through the development of researches that can subsidize practice through their own body of knowledge. The profession must keep sight of its unique attributes, which include their presence with the patient, listening, and care. These values cannot be minimized nor forgotten, since, although other professions and the use of technologies can provide health care, only nurses can voice the most profound human needs ${ }^{(15)}$, and their care continues to be irreplaceable to maintain life.

For nursing to reach its professional autonomy, Freidson believes that this profession, which he characterizes as a "combative occupation"(4:89), must assume complete control over their work ${ }^{(4)}$. However, interdependence, coparticipation, and the sharing of knowledge and abilities are important, as long as the legal and ethical limits of each organization are respected, and no profession can have domain over another ${ }^{(10)}$.

During a pandemic, such as the COVID-19 one, infection control, patient-focused care, and the need for teamwork are greater. Furthermore, it is considering their previous experiences that nurses learn to become more resilient in 
times of crisis ${ }^{(16)}$, and can feel more prepared to act with autonomy and expertise, assuming the main role in their activities and developing their abilities.

Expertise is defined as a complex body of knowledge that leads to an extraordinary autonomy in the control of both the definition of the problems and of the way in which professionals perform their practices, becoming experts in certain functions ${ }^{(4)}$. The activities for which a profession is responsible"can be judged by their fidelity to the knowledge and by the degree to which this practice is based on that knowledge $\left.{ }^{\prime \prime 4}: 365\right)$. With regard to nursing, it is important to mention that being an expert in the field is related to valuable contributions of the professionals, not only in the field of assistance but also in the fields of education, research, and management, considering that the knowledge, when based on scientific evidence, is an important ally that gives meaning to the practice.

Additionally, the expertise of nurses, when associated to the implementation of Nursing Care Systematization (SAE) and to the application of Nursing Theories in their daily practice, bestows more legitimacy upon their autonomy to act with "such an exceptional level of skill and knowledge of their professional work that laypeople cannot evaluate and regulate it"(4:159). Therefore, from the point where nurses plan and prescribe the care they believe necessary for a COVID-19 patient, these professionals show themselves to have expertise enough to act in the frontlines, with autonomy and technical-scientific competence.

Considering that this type of autonomy represents the freedom to choose between different actions, one consequence of this freedom is that professionals must be willing to take responsibility for their choices and actions ${ }^{(11)}$. Freidson states that, for the autonomous exercise of a profession, it must be capable of taking control over the performance of its practitioners, with no external interferences, and it must be able to enforce its own rules, on its own.

According to Freidson's approach, this control is characterized by self-regulation, which allows the professional to guarantee that they are performing their work correctly and justifies their ethical demands, which are a necessary condition to guide their practice with autonomy, towards the public interest ${ }^{(4)}$. Freidson believes that "self-regulation is the test of professional autonomy"(4:106).

Nurses are pioneers in the development of the best practices for the management and clinical safety of patients. Their ability and efficiency are even greater during crises, wars, disasters, and pandemics of infectious diseases, such as COVID-19(17). Therefore, they are expected to take greater control over the work of the nursing team, to guarantee a safe and qualified assistance.
A pandemic requires the work of nurses always involved in broad-scope planning, training, and education, so they are better prepared to deal with new problems during the outbreaks of new diseases ${ }^{(17)}$. They must be increasingly committed to the offering of assistance care, based on their expertise and on their self-regulating power, and are capable of reaffirm their autonomy in the concrete exercise of the profession.

In the midst of the uncertainties with regard to the virus, there is no doubt that, at the end of the pandemic, nursing and the provision of health care will be stronger and better prepared to face future challenges ${ }^{(9)}$. However, only time can tell whether the practices implemented by nurses to manage the new coronavirus pandemic will remain, after this period of public calamity is over.

\section{— FINAL CONSIDERATIONS}

The role of nursing professionals around the world during the crisis of the new coronavirus has been complex and challenging. Their work, which is crucial for the combat against the propagation of the virus, its prevention, and for the recovery of those infected by the pandemic, has become more visible due to media coverage. In this context, reflections emerged about the exercise of the professional autonomy of the nurses in times of pandemic.

With this in mind, many ideas of Eliot Freidson were used, which provided a rich theoretical-methodological base to the discussions brought in this reflection. In light of these ideas, this study believes that a profession such as nursing can legitimate its professional autonomy in nursing care through the construction of its status, its ability to self-regulate, and the competence through which nurses show their expertise, to reiterate their commitment to quality public health.

Freidson's approach in the Sociology of Professions encouraged us to ask the following question: how are nurses in the frontline exercising their professional autonomy in this time of crisis? More specifically: how does the performance of these professionals change according to the workplace in which it is exercised during the pandemic of the new coronavirus? These are highly complex questions, whose answers are not within the scope of this reflection article, requiring further quantitative and qualitative studies capable of answering them.

Therefore, this reflection is expected to contribute for the emergence of new researchers about the professional autonomy of nursing, which is a vitally important theme for the continuous development of the profession. It also encourages more debates on higher education institutions, scientific events, and on management and professional 
regulation practices, encouraging professors, frontline professionals, and students to renew their sense of self-value and to become more engaged in the struggle for better working conditions, advocating the importance of nursing during and after the pandemic.

\section{Q REFERENCES}

1. Geremia DS, Vendruscolo C, Celuppi IC, Souza JB, Schopf K, Maestri E. Pandemia Covid-2019: formação e atuação da Enfermagem para o Sistema Único de Saúde. Enferm. Foco. 2020 [cited 2020 Dec 5];11(no esp.):40-7. Available from: http://revista.cofen.gov.br/index.php/enfermagem/article/view/3956

2. World Health Organization (CH). State of the World's Nursing Report- 2020. Geneva: WH0; 2020 [updated 2020 Apr 6, cited 2020 Jun 21]. Available from: https://www.who.int/en/publications/i/item/9789240003279

3. Daly J, Jackson D, Anders R, Davidson PM. Who speaks for nursing? COVID-19 highlighting gaps in leadership [editorial]. J Clin Nurs. 2020;29(15-16):2751-2. doi: https://doi.org/10.1111/jocn.15305

4. Freidson E. Profissão médica: um estudo de sociologia do conhecimento aplicado. 1. ed. São Paulo: UNESP; 2009.

5. Soares SGA, Camponogara S, Vargas MAO. What is said and unspoken about the autonomy of a nurse: (dis) continuity in discourses. Rev Bras Enferm. 2020;73(6):e2019040. doi: https://doi.org/10.1590/0034-7167-2019-0401

6. Melo CMM, Florentino TC, Mascarenhas NB, Macedo KS, Silva MC, Mascarenhas SN. Professional autonomy of the nurse: some reflections. Esc Anna Nery. 2016 [cited 2020 Jun 21];20(4):e20160085. Available from: https://www.scielo.br/ scielo.php?script=sci_arttext\&pid=\$1414-81452016000400601\&lng =en\&n $\mathrm{rm}=\mathrm{is} 0 \& \ln \mathrm{ln}=\mathrm{en}$

7. Amini K, Negarandeh R, Ramezani-Badr F, Moosaeifard M, Fallah R. Nurses' autonomy level in teaching hospitals and its relationship with the underlying factors. Int J Nurs Pract 2015;21(1):52-9. doi: https://doi.org/10.1111/ ijn. 12210
8. Setoodegan E, Gholamzadeh S, Rakhshan M, Peiravi H. Nurses'lived experiences of professional autonomy in Iran. Int J Nurs Sci 2019;6(3):315-21. doi: https:// doi.org/10.1016/j.jijnss.2019.05.002

9. Triviño-Vargas P, Barría RM. Nivel de autonomía de enfermeras en la práctica pediátrica. Una experiencia chilena. Enferm Universit. 2016;13(4):216-25. doi: https://doi.org/10.1016/j.reu.2016.09.002

10. Bellaguarda MLR, Padilha MTI, Nelson S. Eliot Freidson's sociology of professions: an interpretation for Health and Nursing. Rev Bras Enferm. 2020;73(6):e20180950. doi: https://doi.org/10.1590/0034-7167-2018-0950

11. Skår R. The meaning of autonomy in nursing practice. J Clin Nurs. 2010;19(1516):2226-34. doi: https://doi.org/10.1111/j.1365-2702.2009.02804.x

12. Stevenson, A. Shaved heads, adult diapers: life as a nurse in the coronavirus outbreak. The New York Times [Internet]. c2020 [updated 2020 Feb 28, cited 2020 May 11]. Available from: https://www.nytimes.com/2020/02/26/ business/coronavirus-china-nurse-menstruation.html

13. Jackson D, Bradbury Jones C, Baptiste D, Morin K, Neville S, Smith GD. Life in the pandemic: some reflections on nursing in the context of COVID-19 [editorial]. J Clin Nurs. 2020;29(13-14):2041-3. doi: https://doi.org/10.1111/jocn.15257

14. Masters K. Nurse practitioners say supervision requirements are a hindrance amid COVID-19 pandemic. Virginia Mercury [Internet]. 2020 [updated 2020 Apr 13, cited 2020 Jun 8]. Available from: https://www.virginiamercury. com/2020/04/13/nurse-practitioners-say-supervising-requirements-arebecoming-a-problem-amid-covid-19-pandemic/

15. Oliveira KKD, Freitas RJM, Araújo JL, Gomes JGN. Nursing Now and the role of nursing in the context of pandemic and current work. Rev Gaúcha Enferm. 2021;42(esp):e20200120. doi: https://doi. org/10.1590/1983-1447.2021.20200120

16. Duncan D. What the COVID-19 pandemic tells us about the need to develop resilience in the nursing workforce. Nurs Manag (Harrow). 2020;27(3):e1933. doi: https://doi.org/10.7748/nm.2020.e1933

17. Buheji M, Buhaid N. Nursing human factor during COVID-19 pandemic. Int J Nurs Sci. 2020;10(1):12-24. doi: https://doi.org/10.5923/j.nursing.20201001.02 
- Authorship contribution:

Concept: Rafaela Lira Mendes Costa.

Data selection: Rafaela Lira Mendes Costa.

Formal analysis: Regina Maria dos Santos e Laís de

Miranda Crispim Costa.

Investigation: Rafaela Lira Mendes Costa.

Methodology: Rafaela Lira Mendes Costa, Regina Maria

dos Santos e Laís de Miranda Crispim Costa.

Supervision: Regina Maria dos Santos e Laís de Miranda

Crispim Costa.

Writing - original draft: Rafaela Lira Mendes Costa,

Regina Maria dos Santos e Laís de Miranda Crispim

Costa.

Writing - revision and editing: Rafaela Lira Mendes

Costa, Regina Maria dos Santos e Laís de Miranda

Crispim Costa.

\section{- Corresponding author:}

Rafaela Lira Mendes Costa

E-mail: rafaelaliramc@gmail.com

\section{Associate editor:}

Dagmar Elaine Kaiser 